2014

\title{
Cultural Imaginary, the Rule of Law, and (Post-) Colonialism in Indonesia: Perspectives from Pramoedya Ananta Toer's This Earth of Mankind
}

Jeffrey E. Thomas

University of Missouri Kansas City

Follow this and additional works at: http://ro.uow.edu.au/ltc

\section{Recommended Citation}

Thomas, Jeffrey E., Cultural Imaginary, the Rule of Law, and (Post-) Colonialism in Indonesia: Perspectives from Pramoedya Ananta Toer's This Earth of Mankind, Law Text Culture, 18, 2014, 101-126.

Available at:http://ro.uow.edu.au/ltc/vol18/iss1/7 


\title{
Cultural Imaginary, the Rule of Law, and (Post-) Colonialism in Indonesia: Perspectives from Pramoedya Ananta Toer's This Earth of Mankind
}

\author{
Abstract \\ This article focuses on culture and rule of law in Indonesia, which provides an excellent case study in \\ colonialism and post-colonialism. The colonial heritage of the Indonesian islands goes back to the early $1500 \mathrm{~s}$ \\ and lasted for approximately four centuries (Schultz 2002:144-145) until independence was declared in \\ August 1945 (GoGwilt 1996: 158). This Earth of Mankind by Pramoedya Ananta Toer is an appropriate text \\ through which to view the issues surrounding colonialism and post-colonialism because it represents the \\ struggle of a Native Indonesian with various colonial institutions at the turn of the 19th Century; these \\ struggles have been chronicled by an author who lived through colonial rule, Japanese occupation, and \\ liberation. In addition, the narrative is interesting because Parmoedya1 had been imprisoned by the Colonial \\ Dutch, and then again by Indonesian authorities, for his literary activities (Samuels 1999). This Earth of \\ Mankind, perhaps Pramoedya's most popular novel, was written (more accurately 'recited') during his \\ fourteen-year imprisonment on Buru Island (Lane 1991). Pramoedya has won several writing awards \\ (GoGwilt 1996: 149), and has been nominated several times for the Nobel Prise in literature (BBC News \\ 2006). He 'has long been recognised as Indonesia's most significant literary voice' (GoGwilt 2003: 217).
}




\section{Cultural Imaginary, the Rule of Law, and (Post-) Colonialism in Indonesia: Perspectives from Pramoedya Ananta Toer's This Earth of Mankind}

\section{Jeffrey E Thomas}

\section{Introduction}

This article focuses on culture and rule of law in Indonesia, which provides an excellent case study in colonialism and post-colonialism. The colonial heritage of the Indonesian islands goes back to the early 1500s and lasted for approximately four centuries (Schultz 2002:144145) until independence was declared in August 1945 (GoGwilt 1996: 158). This Earth of Mankind by Pramoedya Ananta Toer is an appropriate text through which to view the issues surrounding colonialism and post-colonialism because it represents the struggle of a Native Indonesian with various colonial institutions at the turn of the $19^{\text {th }}$ Century; these struggles have been chronicled by an author who lived through colonial rule, Japanese occupation, and liberation. In addition, the narrative is interesting because Parmoedya ${ }^{1}$ had been imprisoned by the Colonial Dutch, and then again by Indonesian authorities, for his literary activities (Samuels 1999). This Earth of Mankind, perhaps Pramoedya's most popular novel, was written (more accurately 'recited') during his fourteen-year imprisonment on Buru Island (Lane 1991). Pramoedya has won several writing awards (GoGwilt 1996: 149), and has been nominated several times for 


\section{Thomas}

the Nobel Prise in literature (BBC News 2006). He 'has long been recognised as Indonesia's most significant literary voice' (GoGwilt 2003: 217).

This article begins with a framework for analysis of the cultural imaginary based on recent work of Desmond Manderson. He identified three methods for law and literary analysis: the mimetic, the romantic and modernism (2012). Although Manderson criticises the mimetic and romantic approaches, and offers modernism as the superior method, all three will be used in this paper. The mimetic and romantic approaches are well-established techniques for law and literature, and while modernism makes more complete use of the literary form, the mimetic and romantic generate worthwhile insights. After summarising the method of analysis, the article will outline two main tenets for assessing the rule of law before applying the methods and the rule of law standards to the narrative in This Earth of Mankind. In doing so, it will show that the colonialism's use of law, at least from the perspective of the colonised, was inconsistent with core tenets of rule of law. It also shows that the narrative includes persuasive arguments critical of colonial rule of law. More importantly, it will show that the narrative provides a more nuanced depiction of law and colonialism, including a showing that non-colonial practices were even less consistent with rule of law and that colonialism empowered the colonised so as to promote the rule of law, although without success in the narrative.

\section{Cultural Imaginary}

Literature is just one example of the cultural imaginary, but is one that has come to be recognised as an 'intellectual discipline' (Manderson, 2012: 10). Significant contributors to this field include James Boyd White (1985, 1990), Desmond Manderson (2012), Martha Nussbaum (1997), Ian Ward (1995, 1999), Robin West (1985), and Melanie Williams (2002). It is within that tradition that this article explores This Earth of Mankind. 
Notwithstanding a robust scholarly literature, no consensus has developed regarding the methodology of law and literature. However, Desmond Manderson has suggested that most law and literature works use either a 'mimetic' or 'romantic' approach (Manderson, 2012). The mimetic approach generally treats literature as an accurate depiction of the world and then undertakes an analysis of that depiction as 'evidence in support of some specific truth-claim' (2012:10;11). Manderson criticises this approach as a 'fallacy' because a particular piece of literature has no special claim on 'truth', especially to the exclusion of other literary and non-literary works. Moreover, treating literature as 'true' reduces it to being treated according to the 'terms with which law is familiar: the language of facts, or proof and of generalisation and reduction' (2012:11). This treatment misses 'the real strength of literature ... its openness to multiple interpretations and to the dialog with different readers that it inaugurates' (2012:12). It also ignores much of what makes literature distinctive, 'form, language, style [and] characters' (2012:12).

The romantic approach adds more to legal analysis than the mimetic approach does. However, like the mimetic approach, it also fails to take full account of literary forms. The romantic approach uses literature to bring additional perspective to law, 'to enrich our thinking about law and justice' (2012:10). Manderson uses the example of Martha Nussbaum's Poetic Justice, which he notes has been 'enormously influential' and of which he is 'a great admirer' (2012:12). While he concedes Nussbaum's point that literature has the power to allow readers 'imagine what it is like to live the life of another person' (2012:12; Nussbaum 1995:5), he rejects this instrumental use of literature as incomplete and ideological. The use is incomplete because it collapses the literary narrative to a single, predominant perspective with a political end (2012:14). It is ideological because the literary work will be chosen in part based on the ideological message it conveys (2012:14). The romantic approach misses the diversity of perspectives and meanings, and fails to fully embrace the experience of reading literature, which is affected by form and style (2012:15). 


\section{Thomas}

In the place of the mimetic and romantic approaches, Manderson suggests 'modernism':

Modernism asks us to understand art of literature as an exercise in style, form and language, and in the diversity of voices and perspectives it opens to us. In both ways we might say that modernism rejected the upright aesthetic ideologies of previous eras and opened up the claims of truth and perfection to the destabilizing force of irony (2012:9-10).

This 'diversity of voices' is what Mikhail Bakhtin called the 'polyglossia' or 'polyphony' of literature (1981:308), which, as Manderson describes, 'brings to life the multiple voices and multiple points of view' (2012:16). This diversity creates the setting for irony, an important literary device for the novel and for the approach of modernism. As defined by Manderson, irony is;

the juxtaposition of intentional meaning against context and causality that remains external to the speaking voice - even, sometimes, to the voice of the author - and thereby destabilises the meaning of a text (2012:17).

This destabilisation - along with style, form and language - engages the reader's imagination and creates a distinctive literary experience.

The approach of modernism seeks to use this experiential dimension of literature as part of the analysis of law and literature. Manderson puts it this way:

To reduce literature to some moral lesson is to fail to see what it is really about. We remember how we were and how we felt when we read a particular novel much more than we remember what it was about. It transforms us by becoming an agent in our lives rather than a principle we memorise or an end-point we reach. The field of law and literature typically has responded by transforming literature itself into an endpoint. ... As we have seen this approach is ultimately selfdefeating because it misses the experiences and ambiguities that bring us to literature in the first place. (2012: 20).

The experience of literature is the point of reading it. This experience has 'the capacity to produce and extend a desire to act, not by the facts it imparts, but by the energy, vitality and expressiveness it conveys' (2012: 16). 
This article will use Manderson's framework for exploring the law and literature implications of This Earth of Mankind. In addition to modernism, Manderson's recommended approach, this article will also apply the more traditional mimetic and romantic approaches.

\section{The Rule of Law}

Because the 'rule of law' is the point of reference for analysis, we must begin with a brief discussion of what is meant by that phrase before we turn to the application of the law and literature methods. The meaning of 'rule of law' is uncertain and highly contested; although no consensus appears to be developing (see Carlin \& Sarsfield 2012; Belton 2005; Peerenboom 2004; Fallon 1997), scholars tend nevertheless to agree on certain key tenants. Chiefly, the rule of law is meant to restrict governmental power and provide a certain amount of equality before the law as core characteristics, at least as the term is used Western rule of law discourse.

The limitation on governmental power may be the core characteristic of rule of law. This characteristic has a strong historical foundation (Costa 2007: 74; Plucknett 1956: 50-51), and it is nearly universally included within the concept of rule of law (Tamanaha 2012: 236-237; Belton 2005: 4-5). This dimension of the rule of law may be traced back to Plato and Aristotle (Costa 2007: 75-76), and through the Magna Carta and the Bill of Rights (Belton 2005: 8). The specific phrase 'rule of law' is often associated with the work A.V. Dicey, a Ninetieth Century lawyer and professor at Oxford (Fallon 1997: 1). The limitation on governmental power is illustrated by contrasting the 'rule of law' with the 'rule of man' (Fallon 1997: 2-3; Tamanaha 2012: 243-245) or with an absolute or police state (Zolo 2007: 10-11).

The purpose for such a limitation is to protect against arbitrary or capricious exercise of governmental authority. Consequently, a second core concept typically associated with rule of law, namely, a certain amount equality before the law (Belton 2009: 8-9; Dicey 1959:194194). However, such protection of the individual does not necessarily go so far as to protect human rights more generally (Tamanaha 2012: 


\section{Thomas}

233-235; Belton 2005: 7-8; Zolo 2007: 37-38). The extent to which individual or human rights are protected, and the extent to which the legal system promotes liberal democratic values, are used to distinguish between 'thin' and 'thick' theories of rule of law (Peerenboom 2004).

These two core concepts of limitation on governmental power and equality before the law are the aspects of rule of law used for the analysis in this article. They provide the rule of law aspirations against which the narrative from This Earth of Mankind will be measured using the analysis outlined above (mimetic, romantic \& modernism).

\section{This Earth of Mankind - Plot Summary}

This Earth of Mankind is the first book in a tetralogy produced ${ }^{2}$ by Pramoedya Ananta Toer while a prisoner on Buru Island ${ }^{3}$ and was chosen as a highly regarded novel written by one of the most respected of Indonesian writers. ${ }^{4}$ The novel directly provides a Colonial perspective on the operation of law because one of its major conflicts concerns a legal dispute set during Colonial times. The narrative also indirectly provides a Post-Colonial perspective because of the author's own experiences.

This Earth of Mankind relates the story of Minke, a native Javanese who was enrolled in a prestigious Dutch High School in the city of Surabaya in Central Java in 1898. Minke, who is the son of a local leader appointed by the Dutch colonial authorities, is an outstanding student and an exceptionally good writer. His stories, published under a pseudonym, are published in the local newspaper and become the subject of discussion at school.

The narrative follows Minke through his last year of high school as he becomes involved with the Mellema family. The father, Herman Mellema, is Dutch (a 'Pure'). Having taken a Native concubine, who is addressed as Nyai, ${ }^{5}$ the couple have two Indo (mixed-race) children: Robert, who attends the same high school as Minke, and Annelies (known as Ann), who is exceptionally beautiful. Minke first visits the family in the company of a school friend who intends to meet and pursue Ann, but Ann takes an interest in Minke rather than his friend. 
Minke spends considerable time in the Mellema home, ultimately living there part-time. He and Ann become lovers, with Nyai's approval, and are ultimately married according to local Islamic law.

Herman Mellema is largely absent from the family. Having learned Dutch and business practices from Herman, Nyai runs the household and the family's successful dairy business and farm. Minke is astonished by Nyai's flawless Dutch, her directness, and the breadth of her knowledge. Herman makes a brief and embarrassing entrance during one of Minke's visits, leading Minke to learn that Herman spends his time smoking opium and visiting a nearby Chinese-owned brothel.

Robert becomes increasingly estranged from his mother and selfidentifies as a Pure with his father. He is hostile towards Minke, in part because Minke is a Native. Robert eventually drops out of school and, like his father, spends most of his time at the nearby brothel where he is infected with syphilis by a Japanese prostitute. Ann is very close to her mother, and while she is of mixed blood, she self-identifies as Native. Nyai is Ann's mother, teacher, and boss, sheltering Ann from the outside by keeping her close and not allowing her to attend school or develop outside social relationships. Under her mother's tutelage, Ann learns to be an efficient and beloved manager to their many employees, but is emotionally delicate and somewhat spoiled.

One of the primary conflicts of the book is between (on the one hand) Nyai, Ann and Minke, and (on the other hand) Marits Mellema - the son from Herman Mellema's abandoned wife in the Netherlands. Marits, who has become a successful engineer, resents his father for abandoning him and his mother. Marits confronts his father and accuses him of immorality by taking a Native concubine while still being married. This confrontation triggers Herman's leaving Nyai and his children for the escape of opium and the brothel. After learning of Herman's subsequent death, Marits initiates legal proceedings to take control of the Mellema business and guardianship of Ann (who was still a minor under Dutch law). Nyai's and Minke's resistance to these proceedings is the legal conflict upon which this paper focuses. Ultimately, with the Colonial power behind him, Marits prevails over Nyai, Minke and Ann. 


\section{Thomas}

\section{Mimetic Perspective: The Operation of Colonial Law in Indonesia}

The conflict over the business and guardianship of Ann is an archetypal illustration of the operation of Colonial law, a law which protected 'rights' of those with Dutch citisenship at the expense of the Natives. In the novel, the decision about the business and family in Indonesia is issued by a court in Amsterdam based on documents provided by the court in Surabaya. Because there are no 'legal ties' between Herman Mellema and Nyai (they were not married), the court awarded all of the estate to Herman's children. However, the estate is not divided evenly: Marits Mellema is granted a $4 / 6^{\text {th }}$ share, whereas Robert and Anne are allotted $1 / 6^{\text {th }}$ of the estate each. When Robert's whereabouts remain unknown, Martis is appointed the manager of his interest. Because Ann was still a minor, Martis is appointed her guardian and the manager of her share of the estate. As her guardian, the court orders that she be moved to the Netherlands for the remainder of her upbringing (326-327). ${ }^{6}$

Nyai and Minke vow to do everything in their power to fight against the enforcement of the court's order, but to no avail. They attempt to work within the system by hiring a European lawyer who has helped Nyai in business dealings. Although he is willing to fight, he concedes that the 'other side is in the stronger position' (331). Minke realises that means they are going to lose, but feels a 'duty to fight back' (331). After hours of study, Nyai confronts the lawyer who does not deny that they will likely lose. She dismisses the lawyer and vows: 'Even if we don't have a lawyer, we will be the first Natives to oppose the European court, child, Nyo. Isn't that also an honor?' (332).

The failed effort to resist within the system shows the complete failure of the rule of law from the perspective of the colonised people. The limitation on government and equality before the law do not apply to Nyai and Minke as Natives. Nyai doesn't even have standing to resist. She reports on her exchange with the court: 'Actually, our business is only with Annelies, the judge said. You are a nyai, a Native, you have no business with this court' (329). Minke agrees with Nyai's assessment 
that they are powerless and makes the connection to colonialism:

Yes, this was nothing more than a case of the white race swallowing up Natives, swallowing up Mama [Minke's term for Nyai], Annelies, and me. Perhaps this was what was called a colonial case ... a case of swallowing up a conquered Native people (333).

Obviously, from the standpoint of the colonised, this case shows the failure of colonial law to meet the core tenets of rule of law. This case illustrates what Ugo Mattei and Laura Nader have termed the 'dark side' of rule of law (2008: 1). They argue that an 'ethnocentric configuration of institutions and belief systems has produced a powerful Euro-American use of "rule of law" ideology as key to colonial and imperial projects' (Mattei 2008: 1). This use of 'law commonly justifies plunder by hegemonic nations or other powerful actors' (Mattei 2008: 2). 'Plunder' is a good term for what happens to Nyai and Minke. Dutch law was used by a Pure to take away Minke's wife and Nyai's daughter and the business Nyai spent a lifetime building. Although they have resources, understanding, and able legal representation, in the end their status as Natives makes them powerless.

The conflict over the guardianship of Annelise also illustrates the subjugation of local law to the law of the coloniser. Although Minke and Annelise are married under local Islamic law, the court refuses to recognise it. Minke and his supporters challenge the court's indifference. A group of Islamic scholars go to court 'to protest the decision' but in the end 'they were removed by the police especially brought in for that purpose' (340). The scholars then take the matter to the 'Religious Supreme Court' which issues a statement that the 'marriage was legitimate and could not be disturbed or nullified' (343). These efforts make no difference. When enforcing the court order, the judge states: 'We have no business with anyone who claims or who doesn't claim to be her husband. She is still unmarried, without a husband' (344). Thus, the court, using and applying Dutch law, ignores local, Islamic law.

From the perspective of Minke and Annelise (and her mother), this action is contrary to law, and shows the government's unwillingness 


\section{Thomas}

(through the court) to abide by the law. It also shows a lack of equal treatment before the law. Those married under local, Islamic law are not accorded any recognition, while those married under Dutch law are. But this action is only inconsistent with the rule of law if local, Islamic law is recognised as law. From the Colonial perspective, Islamic law does not merit legal recognition. Such a refusal to recognise local law is a form of legal Orientalism, the projection of Western values to determine 'what is and is not law, and who are and are not its proper subjects' (Ruskola 2013: 5). Dutch law, with the conscious omission of local law, was used by colonisers 'for dominating, restructuring and having authority over' Indonesia as part of 'the Orient' (Said 1978: 3). The fact that local law was Islamic makes it even more problematical, as Islam was viewed with some level of contempt as a rival to Christianity (Laffan 2009: 234). As Max Weber, 'the father of legal orientalism' (Mattei 2008: 110), put it, Islamic law is 'traditional prescription and arbitrary decision-making, the latter serving as a substitute for a regime of rational rules' (Weber 1968: 1041).

From a mimetic perspective, this example of a legal dispute over the family business and guardianship of Annelise illustrates the utter failure of the rule of law, at least from the perspective of Minke, Annelise and Nyai. It also illustrates the use of law as an instrument of control and oppression in support of the colonisers. Although Manderson would criticise reliance on such a narrative as a representation of reality, in this case some reliance is justified. The novel is, unfortunately, a reflection of the reality in Indonesia at the time; Pramoedya conducted extensive historical research upon which he relied constructing the narrative (Foulcher 1981: 5, Vickers 1991). Moreover, the presence of this example in a highly regarded Indonesian narrative gives it some significance as a cultural artifact. In the realm of the imaginary, the author has suggested, and the readers seem willing to embrace, the notion that Colonial use of law was in the interests of the colonisers and at the expense of the colonised. This conclusion hardly seems controversial, although it does provide a specific cultural example of an Indonesian anti-Colonial narrative. More significantly, the mimetic perspective sets the stage for the consideration of the romantic 
perspective, which may provide some additional useful insights.

\section{Romantic Perspective: Colonial Law is Unjust}

The patent injustice of the court's ruling in favour of Marits provides an opportunity for the author to make a romantic, persuasive case against the Colonial system. The outcome of the case evokes a feeling of injustice, which is heightened by the reader's affinity for the characters. The narrative evokes sympathy for Minke - who is young, bright, idealistic, and an admirer of Europe and its modern ways - and for Annelise - who is even younger, simple, beautiful, and loyal. Although they are in love, they are separated by an unjust order of the court that was instigated by Marits Mellema, a distant character seeking revenge for the abandonment of his father, Herman Mellema, who was already dead. Minke and Annelise had no control over or responsibility for Herman's abandonment of his family in the Netherlands. Indeed, Nyai does not even know that Herman was married or had a son until Marits appears without warning some five years before Herman dies.

The narrative also evokes sympathy, and perhaps more, even outrage, for the treatment of Nyai. Here is a self-made woman who has learned Dutch, is well-read, and has built and runs the successful family business. She provides for Herman's financial support by paying his bills at the brothel and caring for the family while he does nothing for the business. She is the mother of his two children, whom she raises without his assistance. This is all the more remarkable in light of the fact that she was purchased from her parents to be Herman's concubine. She is considered by many to be barely more than a prostitute, with no expectations beyond pleasing her master. Having accomplished so much with so little, it is outrageous that the court will not recognise Nyai's interest in the business or her daughter.

The futility of the legal proceedings motivates Minke, as a gifted writer, to resort to the press: "All right, Mama, only the pen is left", and so I wrote, calling out, speechifying, complaining, roaring, swearing, crying out in pain, agitating' (343). This provides another opportunity to persuade the reader. In an interview with the publisher for whom 


\section{Thomas}

Minke works, he says of his marriage:

We married of our own accord, and our marriage was approved of by the girl's parents. Our persons are our own property; we are nobody else's property; slavery was abolished by law in 1860 , or so, at least, we have been taught in our history lessons. Now with the impending kidnapping of my wife [to take her to the Netherlands], in accordance with the court's decision, I wish to ask the conscience of Europe: Is that accursed slavery going to be brought back? How can human beings be looked upon purely from the point of view of official documents and without considering their essence as human beings? (341)

Nyai also gives an interview, and makes a case for the injustice of the decision:

For more than twenty years now I have worked my bones, building, defending, and keeping alive this business, both with and then without the late Herman Mellema. I've looked after this business better than I have my own children. Now it is all being stolen from me. The attitude, illness, and incapacity of the late Mr. Mellema resulted in my losing my first child. Now another Mellema is going to steal my youngest also. Through the use of European law, he is having me torn from all that is mine by right, and all that I love. If that is indeed his deliberate intention towards us, all I can do is ask: What is the point of having all these schools if they still don't teach what are people's rights and what are not, what is right and what is not? (340)

Their arguments are compelling, especially in light of the circumstances outlined in the narrative. The reader who identifies with these characters will feel their outrage and frustration, and will feel motivated, at least in the fictional world, to help. The narrative captures that motivation through the reaction of the people who are reading the papers and listening to others read the papers out loud. Although the people have put up with such injustice all of their lives without protest, 'dumb like the river stones and the mountains, ... What a roar there would be if they all spoke out as we will now speak out. Perhaps even the sky itself would be shattered by the din' (335).

Upon learning of the court's intention to enforce the ruling, the 
people do 'speak out' in the form of a physical protest in support of Minke, Nyai and Annelise, 'A crowd of Madurese, armed with machetes and large sickles, had surrounded our house, and were attacking any Europeans or state employees who tried to enter our compound' (344). Alas, while Minke and Nyai appreciate the support, ultimately (and despite the fact that several people are killed in the process), the protests only cause a modest delay in the enforcement of the court's order. To quell the demonstration, the government replaces the local police with a company of the Marechaussee, 'a special command made up of specially chosen troops of the Netherlands Indies Army ... famous as a company of fighters' (345). While the Madurese are fierce, persistent fighters, they were no match for better trained and equipped Marechaussee.

The romantic perspective adds an additional level of perspective and persuasion to the mimetic. Because of the reader's relationship to the characters, the narrative evokes sympathy. The arguments raised by the characters show the hypocrisy of Colonial rule by suggesting that the court order is a form of slavery (which had been abolished some years before) and by invoking the concept human rights. The reader is moved in support of the protestors, with hopes of victory or at least that the Colonial authorities may relent, but in the end the order is carried out, leaving the reader in the same state as Minke and Nyai. Manderson would criticise this as an ideological use of a narrative to promote anti-Colonialism. While this is a legitimate criticism, the same point can be made of any method of advocacy. It is up to the proponents to Colonialism to advance a contrary narrative with its own romantic appeal. That will not be easy in the contemporary climate. The romantic momentum is very much against Colonialism. In contemporary society, few would seriously consider defending the fairness or justice of the Colonial system.

\section{Modernism: Irony, Empowerment \& Aesthetics}

Manderson's modernism goes beyond both the mimetic and romantic perspective because it explores these ideas rather than promoting a 


\section{Thomas}

particular perspective about them. It suggests that the power of literature is that it allows the reader to experience the concepts from multiple perspectives, which can promote a deeper understanding and reflection. This exploration can take the form of irony, and may be influenced by the author's use of style, form and language. In the following subsections, we will consider how the narrative uses irony, empowerment and aesthetics to represent its core ideas.

\section{A Irony}

The modernist use of irony sets intentional meaning at odds with context and causality. Using this approach to read This Earth of Mankind takes us beyond the obvious anti-Colonial examples and rhetoric by contextualising them in a setting that includes pro-Colonial elements as well. The tension between the anti-Colonial and the pro-Colonial generates a significant part of the conflict in the narrative, which leads to a certain amount of positive (anti-Colonial) empowerment.

While at first the pro-Colonial perspective may not be obvious, a closer examination of the characters shows benefits of Colonialism. Nyai, one of the protagonists, is an extraordinary woman because of Colonialism. She is extraordinary in significant part because of her exposure to Dutch language, culture and learning from Herman Mellema. Although he has significant character flaws, he was nurturing and supportive of Nyai at first, teaching her the skills that allow ongoing self-improvement. This positive example of Dutch influence enables her to build a successful business.

Likewise, Minke has benefited from Colonialism. He is an outstanding student, the only Native who graduated first in his class at a prestigious Dutch high school. ${ }^{7} \mathrm{He}$ is greatly influenced by what he learns in school and from certain favourite teachers (inside and outside of class), so much so that he is sometimes accused of becoming more Dutch than Indonesian. He learns to become a gifted writer, but, interestingly, he writes in Dutch, rather than in Malay or Javanese, so must rely on a translator to make his case to the people in the press (336).

Moreover, both Nyai and Minke advance arguments based on 
Western sensibilities of 'rights', rather than arguments grounded in Native values. Nyai, in making her case in an interview, asks: 'What is the point of having all these schools if they still don't teach what are people's rights and what are not, what is right and what is not?' (340; emphasis added). Minke initially frames his around the prohibition against slavery. He analogises the taking of his wife from him to the taking of slaves and asks: 'Is that accursed slavery going to be brought back?' (341). But then he goes a step further, implicating human rights: 'How can human beings be looked upon purely from the point of view of official documents and without considering their essence as human beings?' (341; emphasis added). The use of these European arguments is an example of irony; it is unlikely that Nyai and Minke would have made them if they had not been exposed to European thinking.

These arguments based on human rights are distinctly not Indonesian, that is, at least in terms of the way Indonesian culture (or more precisely Javanese culture) is portrayed in the narrative. Although one might be tempted to assume that the arguments refer to universal rights, such an assumption would reflect a Western bias and projection (especially when considering that the narrative is set in 1899). The Javanese, as depicted, had little use for law and were much more autocratic than the Dutch. This is illustrated by an occasion when Minke is arrested by the police and forced to travel with them for two days: Minke is not given any information about why he has been arrested, where he is going, how long he will be gone, or what will happen when they arrive at the destination. Subsequently, it is revealed that Minke's father, a powerful local leader who was being elevated to the office of a Bupati, had used his power to unilaterally have his son arrested and brought home.

Minke's internal struggle concerning his compliance with local customs illustrates the autocratic authority exercised by local leaders. Minke does not realise at first that he has been summoned home. Instead, Minke is told that he is to meet the Bupati, Minke resents the customs that require total obeisance. On the way to the meeting he laments: 'What's the point in studying European science and learning, 


\section{Thomas}

mixing with Europeans, if in the end one has to cringe anyway, slide along like a snail, and worship some little king who is probably illiterate to boot. God, God!' (121). Custom dictates that Minke walk on his knees to the audience; Minke 'covered the ten meters distance while swearing in three languages' (121). As the Bupati arrives, Minke makes additional gestures of obeisance: 'Obeisance-the lauding of ancestors and persons of authority by humbling and abasing oneself! Level with the ground if possible!' (122). The Bupati used a horse whip made from a bull's genitals to tap Minke on the head, and every tap he 'must greet with a sign of grateful obeisance' (123).

Later, Minke speaks with his mother and shows his total rejection of these Indonesian customs and his embrace of Western values. With pride and affection, his mother predicts that with his education and skills 'he will surely become a bupati one day' (128). Minke rejects this possibility; this surprises his mother, who asks him what he wants to become. He replies: 'I only want to become a free human being, not given orders, not giving orders, Mother” (128). His mother laughs: 'Ha! Will there be a time like that, Gus? This is the first I've heard of it' (128).

This example provides a stark contrast between Javanese conception of hierarchy and power and the Dutch reliance on law and legal procedures. Although the Dutch law did not protect Native rights, at least it protected Dutch and Indo rights. Moreover, this example provides an ironic insight into the anit-Colonial aspects of the narrative. Minke's hostility towards Javanese customs reflects his European sensibilities which he learned at the Dutch school to which he had access because of Colonialism. It is these same sensibilities that give rise to his feelings of outrage and rebellion at the order of the Dutch court. Thus, the only reason we have an anti-Colonial conflict around the court proceeding is because of Minke's adoption of European values that was brought about by Colonialism.

My point here is not mimetic or romantic; I am not suggesting that the representations are necessarily true or that this depiction makes a strong case for a Western ideal of rule of law (although one could make those arguments). Rather, my argument is that the anti-Colonial 
depictions are situated in a more complex setting and narrative (irony), and that those depictions are in tension with what might be termed pro-Colonial implications. This tension allows the reader to experience that conflict from more than one perspective, and may result in different interpretations for different people. While a reader with a Western perspective might use the tension to find positive value in Colonialism, a non-Western reader might consider Minke a kind of 'Uncle Tom' who had abandoned his own culture for that of the Dutch. The narrative tends to move in this latter direction; Minke begins to identify more with Indonesian culture, especially in the next book in the series (Foulcher 1981: 6-7). The difference in possible interpretations may trigger some personal reflection on Colonialism, which is the kind of experience that modernism is trying to get at.

\section{B Empowerment}

The irony in the text illustrates a kind of rule of law irony with Colonialism called 'empowerment' Mattei and Nader (2008:18). Because of the availability of legal recourse, at least for some, some who are oppressed may be empowered to use the legal system to vindicate their rights. This is precisely what Minke and Nyai try to do when they resist enforcement of the court's order with lawyers and legal arguments; but as Natives they did not have sufficient standing or legally recognised rights to be successful. Mattei and Nader note that because of the empowerment effect, 'colonial rulers often entered into alliances with local patriarchal powers, limiting access to the modernised legal system and acknowledging "traditional" power structures (often invented)' (18).

Even though legal recourse is cut off for Nyai and Minke, they persist in their resistance through the press, resulting in widespread public opposition to the order and a confrontation with the government. Because Nyai and Minke owe much of their education and perspective to the Dutch, this shows the Colonisers as sowing the seeds of their own demise. According to Mattei and Nader, 'the rule of law displays a double-edged, contradictory nature: it can favor oppression but it 


\section{Thomas}

can also produce empowerment of the oppressed that leads to counterhegemony' (18). Nyai and Minke, who have embraced the human rights perspectives of Europe, are outraged by the unjust order of the court, and they use rule of law rhetoric in their resistance. Although the counter-hegemony does not change the outcome of the court case, it becomes part of a larger movement against the colonisers that is advanced in Pramoedya's later works of the tetralogy.

The empowerment of Nyai and Minke reflected in the narrative does not prove the truth of the empowerment effect of Colonialism, nor does it provide a 'romantic' argument for or against Colonialism, especially in light of the failure of their efforts. Instead, it provides a narrative explanation as to how the empowerment identified by Mattei and Nader might come to pass. In Minke's case, it is through education and interaction with Pures and Indos. In Nyai's case, it is though selflearning facilitated by the early kindness of Herman Mellema and achieved by hard work and diligence.

The narrative also has a certain prescriptive quality for the reader. It demonstrates methods of resistance, but also warns of the barriers and consequences. It promotes resistance even against the odds, but predicts that if resistance reaches a sufficient scale, it cannot be stopped. Speaking of the people's support, Nyai suggest that 'even the sky itself would be shattered' by collection action (335). This may result in a feeling of empowerment for the reader. Although such empowerment is similar to persuasion of the romantic perspective, modernism's focus on the experience of literature and the multiplicity of meanings triggers reflection that can change one's perspective and behavior.

My own experience with this narrative takes me beyond examples of the injustice of the Colonial legal system (mimetic) and beyond persuasive arguments that the system was unjust (romantic); it caused me to consider neo-Colonial implications my own actions and those of institutions with which I am affiliated. On one hand, the narrative suggests that, like the learning of Minke and Nyai, my teaching can promote Western notions of rule of law that can empower individual and promote justice. On the other hand, the narrative causes me to 
consider whether my activities may promote the use of 'law as part of [European and American] colonialist or imperialist rule, with the colonising powers imposing their own ideas of law on their colonies' (Mattei 2008:65). Thus, the narrative motivates me to search for an appropriate middle path, to promote those beneficial aspects of rights and law while seeking to avoid being imperialistic.

\section{Aesthetics}

Modernism goes beyond the narrative to consider aesthetics - such as style, form, language, and characters. Because of limited space, we will only consider two examples of aesthetics from this text: character and language.

The two protagonists, Minke and Nyai, who become as close as mother and son, are an interesting pairing from the standpoint of rule of law. Nyai, who was sold by her parents into concubinage, is considered to be 'low, dirty, without culture, moved only by lust' and on a par with 'prostitutes' (54). Yet, through her diligence and study, she becomes and successful business woman. Minke, once he meets her is 'amazed' (31) and impressed, so much so that she becomes one of his teachers. Notwithstanding her marginalised status, she is a powerful character (Bahari 2007: 51). Minke, on the other hand, represents the Javanese elite. Of royal blood, the son of a Bupati, his cleverness and heritage put him on the path to power (within certain limits) under Colonial rule.

This pair - who both have faith in European ideals (Nyai from a pragmatic standpoint, Minke as an idealist) - are equally disappointed by the operation of Colonial law. Thus, these characters show that the law fails Natives, regardless of their high or low status, their wealth, their education, or their access to brilliant legal representation. Nyai is particularly interesting as a character because as a concubine, she is governed neither by Colonial law or Indonesian customs (GoGwilt 2007: 409). Indeed, GoGwilt has described her character 'as the very time of heroic anticolonial nationalism' (2007: 410).

Pramoedya's use and exploration of language provides a second aesthetic perspective. Written in Indonesian using a popular rather 


\section{Thomas}

than a literary style, Pramoedya directs the narrative to the masses (Foulcher 1981: 2). This suggests a certain universality of the narrative, which is echoed in Minke's writing about the injustice imposed upon them that is translated from Dutch to Malay and then read aloud in the villages (343). Like the villagers, each reader can make a judgment about justice; it is not just an abstract, technical legal term.

The fact that Minke writes in Dutch, but cannot write in Malay, reflects stratification between the Dutch, Javanese and others who use Malay as a common language. This linguistic stratification runs parallel to the differences in legal treatment based on a person's ethnicity. Consequently, Minke and Nyai, as Natives, are not protected by the Dutch Colonial legal system. Foulcher argues that these differences in language "point the reader towards the use of Indonesian in the text itself, and to the realisation that Indonesian is the appropriate language of the narration' (1981: 8). Similarly, from the standpoint of rule of law, the different legal systems and customs points the reader toward the need for a more university, coherent legal regime.

\section{Historical Context}

The analysis to this point has focused on the text, without recognition of the historical context of the writing and publishing of the novel. This context, however, provides an additional prism for analysis. Two historical facts are of particular note: (1) the novel was written while Pramoedya was imprisoned by the Indonesian military without having been charged with any specific crime and without any legal proceedings, and (2) that the book was banned by the Indonesian government (with possession punishable as a crime) shortly after publication (Samuels 1999). 
Because Pramoedya was under arrest when writing the novel, the narrative may be interpreted as a metaphor for his own experience. His arrest and detention is a failure of law to protect his rights similar to the failure of Colonial law to recognise and protect the rights of Minke and Nyai. Pramoedya's detention is akin to Minke's arrest and transportation home by the police in that both punishments were imposed by Indonesians. Pramoedya undoubtedly objected to this arbitrary use of power, perhaps 'swearing in three languages' just as Minke is described as doing (121). Such arbitrary use of power runs directly contrary the core and nearly universal dimension of the rule of law, that the power of government be limited by law (Tamanaha 2012: 236-237; Belton 2005: 4-5). Thus, the narrative illustrates an absence of rule of law similar to the absence in post-colonial Indonesia, except that after Colonialism the rulers are Indonesian.

While law can serve legitimate (and illegitimate) ends, the narrative suggests that law's protections are not essential to human rights or dignity. According to his publisher:

Pramoedya himself is of the opinion that basic human rights, and, for that matter, his personal civil rights, are not a gift that the government or any other power can bestow on its citizens. The very fact that one is born a human being as an Indonesian citizens makes those rights one's own (Isak 1999).

Dignity comes with standing up for one's rights, even if it is a losing cause. In the words of Minke, even though he knew they 'would be defeated', it was their 'only duty now to fight back, to defend [their] rights, until [they] were unable to fight back any longer' (331).

Pramoedya used the personal dignity of resistance to lift the morale of his fellow prisoners. He explained that the character of Nyai 'emerged as a response' to his imprisonment:

As a woman who stood up, alone, to the injustices of Dutch colonialism, she was a character who provided a model of resistance and courage for my fellow prisoners to look up to, so that their spirit would not be demoralised by the killings and the cruelties witnessed in the [prison] camps (GoGwilt 1995: 156-157). 


\section{Thomas}

Pramoedya likewise resisted efforts to silence him as a writer. Deprived of his ability to write on Buru Island, he recited the stories of the Buru tetralogy to his fellow prisoners; after his release he wrote This Earth of Mankind and published it (GoGwilt 1995). Shortly after publication it was banned by the government (Foulcher 1981: 9).

Although the post-publication banning of the book cannot give us any understanding of the author's meaning, it provides one perspective on its interpretation and significance. The government asserted that the book "contained elements of "class conflict," and, as a result, was a potential hazard to society' (Foulcher 1981: 9). The publisher responded with its own press release suggesting that 'anyone having a proper understanding of the theory of class conflict ... would simply be embarrassed by the suggestion that it was to be found' in the text (Foulcher 1981: 9).

Regardless of whether the narrative promotes class conflict (whatever one's understanding of that may be), the government felt threatened by a perceived subversive message. Even though Minke and Nyai fail in their resistance of Colonial injustice, they represent an example of resistance even against the odds. The Indonesian government seemed concerned that this message might catch on and incite widespread resistance to the government, or even revolution. In retrospect, this perceived threat was overstated, Pramoedya 'aimed with the novel to confront young Indonesian readers with the historical forces which had shaped their present' (Foulcher 1981: 1). ${ }^{8}$ This confrontation may have been provocative. After analysing both the first and second books in the tetralogy (and finding the to be "demonstrably much more "subversive"), Foulcher concluded that the books 'may be said to have revived the socialist alternative view of the novel which was current in Indonesia before 1965' (1981: 15).

\section{Conclusion}

This Earth of Mankind is a masterful story that provides a rich representation of an imagined Dutch Colonial culture in Indonesia. This article has focused on a few selected examples to consider the 
implications for the rule of law. It considered mimetic, romantic and modernism perspectives as outlined by Desmond Manderson to consider the way rule of law is represented. This Earth of Mankind shows Colonial law as inconsistent with core principles of the rule of law from the standpoint of the colonised. It also provides persuasive arguments and strong emotional ammunition in opposition to the injustice of colonial law. While it serves both of these purposes well, limited to these perspectives the narrative would not accomplish very much because of widespread recognition of the problems with Colonialism.

The more meaningful contribution of the narrative comes through the application of modernism where the multiplicity of perspectives starts to unpack contradictions within Colonialism through which the reader may experience empowerment and counter-hegemony as a by-product of Colonialism. The book promotes the dignity of individuals standing up for justice and the need for a more universal language and system for justice. In its historical context, it represents Pramoedya's personal statement of dignity in face of injustice and an effort to confront Indonesians with their past and to challenge them to build a collective future.

\section{Notes}

Jeffrey E Thomas is Associate Dean, Daniel L. Brenner Faculty Scholar and Professor of Law at the School of Law, University of Missouri Kansas City (thomasje@umkc.edu).

1 I will follow Indonesian custom and refer to the author by his first given name.

2 I use the term "produced" because the novels were originally recited during Pramoedya's imprisonment when he did not have access to writing materials. After his release, Pramoedya put them into written form for publication.

3 Consequently, the tetralogy is often referred to as the Buru Quartet. 


\section{Thomas}

4 Pramoedya Ananta Toer was nominated several times for the Nobel prize for literature, and was 'the only Indonesian to appear on a list of 100 leading intellectuals named by British magazine Prospect' (BBC News 2006).

5 The term Nyai in Colonial times was a derogatory term to refer to concubines taken by Dutch me (Suryakusuma 2010).

6 Page references to specific passages of the novel will be used at key points of the discussion.

7 Actually, one other student is a Native, but he was adopted by a Dutch couple and given a Dutch name, Jan Dapperste, so passes as an Indo in school (of mixed race). Ultimately, he embraces his Native identity, changes his name to Panji Darman, and leaves his adoptive parents.

8 Citing an interview of Pramoedya Ananta Toer in Tempo (August 301980 ).

\section{References}

Bahari R 2007 'Between a Rock and a Hard Place? Interstitial Female Subjectivity in Between Colonialism and Patriarchy: Women in Pramoedya Ananta Toer's Buru Tetralogy' Indonesia 83: 41-77

Bakhtin M 1981 'The Discourse in the Novel' in Holquist 1981: 259-422

- 1990 'Author and Hero in Aesthetic Activity' in Holpquist and Liapunov 1990: 4-256

BBC News 2006 'Author Pramoedya Ananta Toer dies' April 30 Available from http://news.bbc.co.uk/2/hi/entertainment/4959488.stm Last accessed June 182014

Belton R 2005 Competing Definitions of the Rule of Law: Implications for Practitioners Carnegie Endowment for International Peace Washington

Dicey A 1959 Introduction to the Study of the Law of the Constitution Macmillan London ( $2^{\text {nd }}$ edn first published in 1915)

Carlin R and R Sarsfield 2012 'Rethinking the Rule of Law: Concepts, Measures and Theory' Justice System J 33/2:125-130

Costa P 2007 'The Rule of Law: A Historical Introduction' in Costa and Zolo 2007: 73-152

- and D Zolo eds 2007 The Rule ofLaw: History, Theory and Criticism Springer Dordrecht 


\section{Cultural Imaginary, the Rule of Law, and (Post-) Colonialism in Indonesia}

Fallon R 1997 “'The Rule of Law” as a Concept in Constitutional Discourse' Columbia $L R$ 97/1:1-56

Foulcher K 1981 'Bumi Mansuia and Anak Semua Bangsa: Pramoedya Ananta Toer Enters the 1980s’ Indonesia 32/1: 1-15.

GoGwilt C 1996 'Pramoedya's Fiction and History: An Interview with Indonesian Novelist Pramoedya Ananta Toer' Yale J of Criticism 9/1: 147-164

- 2003 'The Voice of Pramoedya Ananta Toer: Passages, Interview and Reflections from he Mute's

Soliloquy and Pramoedya's North American Tour' Cultural Critique 55: 217-246

- 2007 'The Vanishing Genre of the Nyai Narrative: Reading Genealogies of English and Indonesian

Modernism' Comparative Literature Studies 44/4: 409-433

Harris W 1990 'Bakhtinian Double Voice in Eliot and Dickens' ELH 57/2: 445-458

Holquist M ed 1981 The Dialogic Imagination: Four Essays by MM Bakbtin Trans C Emerson and M Holquist University of Texas Press Austin

- and V Liapunov eds 1990 Art and Answerability: Early Philosophical Essays Trans V Lipunov University of Texas Press Austin

Isak J 1999 'Epilogue' in Toer P 1999: 368-71

Laffan M 2011 The Makings of Indonesian Islam: Orientalism and the Narration of a Sufi Past Princeton University Press Princeton

Lane M 1991 'Afterward' in Toer 1996: 361-63

Manderson D 2012 Kangaroo Courts and the Rule of Law: The Legacy of Modernism Routledge Abingdon

Mattei U and L Nader 2008 Plunder: When Rule of Law is Illegal Blackwell Publishing Malden Oxford

Nussbaum M 1995 Poetic Justice Beacon Press Boston

Peerenboom R 2004 'Varieties of Rule of Law: An Introduction and Provisional Conclusion' in Peerenboom ed 2004: 1-53

- ed 2004 Asian Discourses of Rule of Law: Theories and implementation of rule of law in truelve Asian countries, France and the U.S. Routledge Curzon London 


\section{Thomas}

Plunkett T 1956 A Concise History of the Common Law Little Brown and Company Boston ( $5^{\text {th }}$ edn)

Ruskola T 2013 Legal Orientalism: China, the United States and Modern Law Harvard University Press Cambridge

Said E 1978 Orientalism Pantheon Books New York

Samuels W 1999 'Introduction' in Toer 1999: xii-xxiii

Sontag S 2001 'Against Interpretation' in Against Interpretation and Other Essays Picador New York

Suryakusuma J 2010 'Indonesia: “The Nyai Nation”' The Jakarta Post August 8 Available from http://www.thejakartapost.com/news/2010/08/08/ indonesia-039the-nyai-nation039.html Last accessed June 182014

Tamanaha B 2012 'The History and Elements of the Rule of Law' Singapore J Leg Studies 2012: 232-247

Toer P 1996 This Earth of Mankind Trans M Lane Penguin New York

- 1999 The Mute's Soliloquy: A Memoir Trans W Samuels Hyperion East New York

Vickers A 1991 'Reading Pramoedya Ananta Toer and Writing Indonesian Cultural History' New Literatures $R$ 22: 82-102

Ward I 1995 Law and Literature: Possibilities and perspectives Cambridge University Press Cambridge

- 1999 Shakespeare and the Legal Imagination Butterworths Oxford

Weber M 1968 Economy and Society: an Outline of Interpretive Sociology University of California Press Berkeley

West R 1985 'Authority, Autonomy, and Choice: The Role of Consent in the Moral and Political Visions of Fanz Kafka and Richard Posner' Harv LR 99/1:384-428

White J 1985 Heracle's Bow: Essays on the Rhetoric and Poetics of the Law University of Wisconsin Press Madison

- 1990 Justice as Translation University of Chicago Press Chicago

Williams M 2002 Empty Justice: One Hundred Years of Law, Literature and Philosophy: Existential, Feminist and Normative Perspectives in Literary Jurisprudence Cavendish Abingdon

Zolo D 2007 'The Rule of Law: a Critical Reappraisal' in Costa and Zolo 2007: 3-72 